\title{
Process-based primary production modeling in Chesapeake Bay
}

\author{
Carl F. Cerco*, Mark R. Noel \\ Mail Stop EP-W, US Army Engineer Research and Development Center, 3909 Halls Ferry Road, Vicksburg, \\ Mississippi 39180, USA
}

\begin{abstract}
A primary production model is described and compared to 3 observational data bases: light-saturated carbon fixation, net phytoplankton primary production, and gross phytoplankton primary production. The model successfully reproduces the observations while maintaining realistic calculations of algal carbon, chlorophyll, limiting nutrient, and light attenuation. Computed primary production in light-limited regions is proportional to the algal growth rate. Successful computation of primary production in nutrient-depleted waters depends on the formulation and magnitude of the model predation term. Our quadratic formulation mimics a predator population that is closely coupled to algal biomass and rapidly recycles nutrients from algal biomass to available form.
\end{abstract}

KEY WORDS: Chesapeake Bay $\cdot$ Primary production $\cdot$ Phytoplankton $\cdot$ Mathematical models Resale or republication not permitted without written consent of the publisher

\section{INTRODUCTION}

Primary production models may be placed in 2 categories: 'observation-based' and 'process-based.' Observation-based models (Behrenfield \& Falkowski 1997) employ observations of a photoadaptive variable, chlorophyll, and perhaps other quantities, to quantify depthintegrated production at the time and location of the observations. Process-based models quantify production as a function of computed algal biomass and computed processes that may include growth, respiration, predation, and transport. Parameters in process-based models are usually assigned so that computations match 1 or more observed quantities.

Process-based models frequently encounter difficulty in simultaneously matching observed biomass and production (Brush et al. 2002). Most commonly, process-based models represent biomass but fall short in computing production. Less commonly, the models adequately compute production but misrepresent biomass and/or growth-limiting nutrient concentration.

For example, Doney et al. (1996) modeled phytoplankton, zooplankton, and nutrients in a subtropical region near Bermuda. They noted that the model showed 'skill in capturing the major features of the annual chlorophyll field.' Computed primary production, however, was almost always less than observed. Model performance was weakest 'during late summer, when the model cannot supply enough nutrients to support the high production observed.' Similarly, McGillicuddy et al. (1995) showed computed and observed vertical profiles of primary production in the North Atlantic. In 10 of 13 cases, primary production was under-computed at the surface, where light is abundant and nutrients are scarce. In deeper waters, where light is attenuated and nutrients are more abundant, model-data comparisons were much improved.

In contrast, Fasham et al. (1990) calibrated a model that included phytoplankton, zooplankton, bacteria, and nutrients to match observed primary production at Ocean Stn 'S' near Bermuda. During the summer, computed nitrate concentrations were much less than observed. Their simulations 'greatly overestimated the phytoplankton biomass in the summer and autumn.'

Moll (1998) also found that observed primary production rates were well-matched in a model of North Sea chlorophyll, phosphate, and primary production. At several stations, the computed phosphate exceeded that observed by several hundred percent. At all stations, the computed concentrations exceeded the 
specified half-saturation values by 2 to 3 times. Consequently, computed production was not nutrientlimited.

Based on these and other studies, the following generalizations appear to hold for process-based models of primary production. Observed production can be matched when light rather than nutrients appears to limit production (the North Atlantic at depths greater than 20 to $30 \mathrm{~m}$, the North Sea as modeled). In regions where nutrients appear to be more limiting than light (North Atlantic surface waters, the subtropical Atlantic), observed production cannot be computed without compromising computations of algal biomass and nutrients (Ocean Stn ' $\mathrm{S}$ '). The objective of the present study was to create a process-based model of Chesapeake Bay that simultaneously matches observations of phytoplankton biomass, limiting nutrient concentration, light attenuation, and primary production.

\section{MODEL}

Chesapeake Bay. Chesapeake Bay is an extensive estuarine system located on the east coast of the USA (Fig. 1). The bay extends $300 \mathrm{~km}$ from the Susquehanna River at its head, to the Atlantic Ocean at its mouth. The mean depth is $8 \mathrm{~m}$, although a deep trench with depths of up to $50 \mathrm{~m}$ runs up its center. The Susquehanna provides the majority of freshwater flow (64\%) and nutrient-loading (Malone et al. 1988, Boynton et al. 1995). Virtually all remaining runoff and loads originate from several western tributaries. The bay and major tributaries are classic examples of partially mixed estuaries by Pritchard's (1967) classification.

Extensive studies of the bay describe a system in which phytoplankton biomass and production are out of phase. Peak biomass occurs during the spring bloom while peak production occurs concurrent with the summer temperature maximum (Malone et al. 1988, Smith \& Kemp 1995, Malone et al. 1996, Harding et al. 2002). During the spring bloom, phosphorus and silica tend to be the limiting nutrients, while nitrogen is the primary limiting nutrient in summer (Fisher et al. 1992, 1999, Malone et al. 1996). Nitrogen loads delivered during spring runoff are coupled to summer production through a nutrient-trapping mechanism. Nitrogen present in spring runoff is taken up during the phytoplankton bloom, deposited in bottom sediments, and recycled to the water column by temperature-induced diagenesis (Malone et al. 1988).

Chesapeake Bay environmental model package (CBEMP). The CBEMP is a system of models comprising a 3-dimensional hydrodynamic model (Johnson et

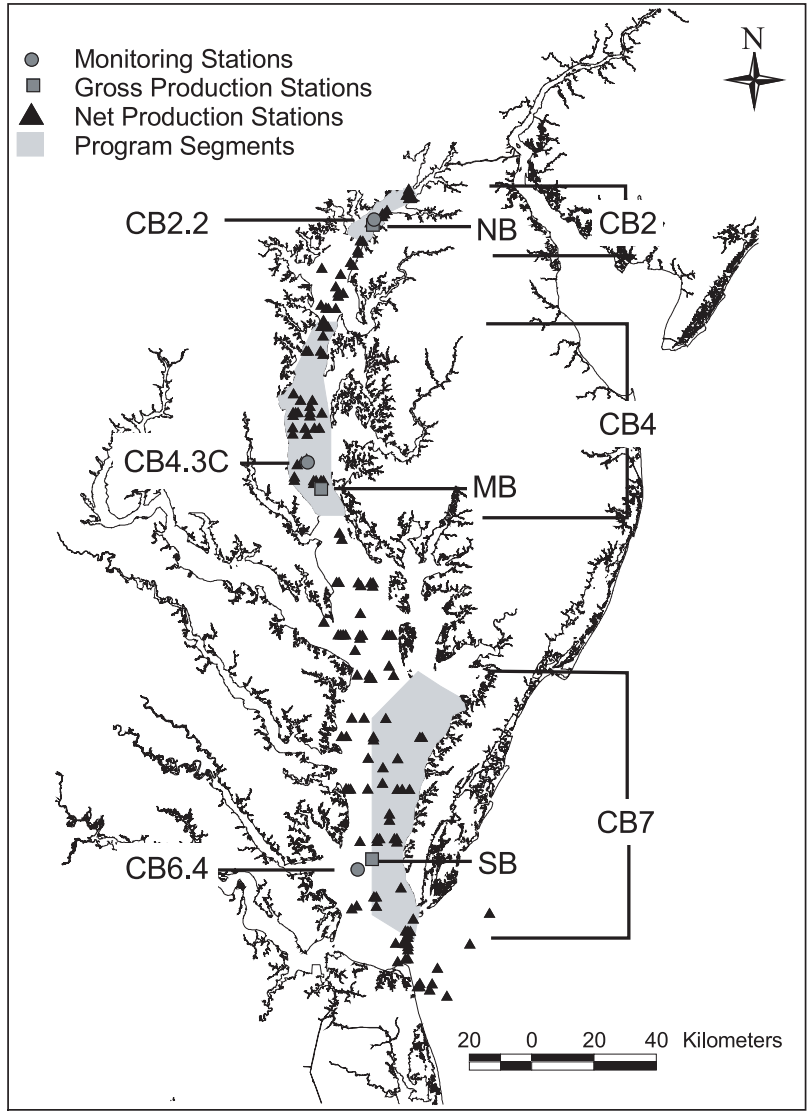

Fig. 1. Chesapeake Bay showing location of primary production sampling stations

al. 1993), a eutrophication model (Cerco \& Cole 1993, Cerco \& Meyers 2000), and a sediment diagenesis model (DiToro 2001). The CBEMP was developed to assist management of eutrophication within Chesapeake Bay and tributaries. Since management involves attaining water quality standards, emphasis in the model was placed on representing observed properties including nutrients, chlorophyll, dissolved oxygen, and light attenuation.

The CBEMP is a process-based model. Primary production calculations in initial versions of the CBEMP were consistent with characteristics of other processbased models. Computed production matched or exceeded observed production in the turbidity maximum region of the bay, where nutrients are abundant but light is limited; however, in the middle and lower portions of the bay, where light attenuation is diminished but nutrients are sparse relative to the turbidity maximum, computed production fell short of that observed.

Management efforts in the Bay now require investigation of the effects of filter-feeders, especially oysters and menhaden, in reducing eutrophication. Hence the 
amount of production available to these organisms must be well represented. At the same time, use of the model to examine water-quality standards cannot be neglected. Consequently, the CBEMP must now represent both properties of the system and production rates.

Data bases. Light-saturated carbon fixation $\left(C_{\text {fix }}\right)$ : Phytoplankton photosynthetic rates were measured 12 to 18 times per year at 6 stations in the upper portion of the bay. Methodology was a ${ }^{14} \mathrm{C}$ technique outlined by Strickland \& Parsons (1972). Rates were reported as $\mu \mathrm{C} \mathrm{l}^{-1} \mathrm{~h}^{-1}$. For consistency with other measures of production and model units, reported rates were converted to $\mathrm{g} \mathrm{C} \mathrm{m}^{-3} \mathrm{~d}^{-1}$ even though these data represent a short-term, nearly-instantaneous rate and should not be confused with daily carbon fixed. The data base for the period 1985 to 1994 was obtained from the US Environmental Protection Agency Chesapeake Bay Program monitoring database (www.chesapeakebay. net/data/index.htm).

Net phytoplankton production (NPP): NPP was measured via a ${ }^{14} \mathrm{C}$ method conducted in shipboard incubators at in situ temperatures (Harding et al. 2002). More than 160 observations, conducted throughout the bay (Fig. 1), were provided for the period 1987 to 1994 . Integral daily NPP was reported as $\mathrm{mg} \mathrm{C} \mathrm{m}^{-2}$.

Gross primary production (GPP): GPP was measured by an oxygen evolution method (Smith \& Kemp 1995). Roughly 60 measures, collected in the interval 1989 to 1992, were collected at 3 stations (Fig. 1). Daily GPP was reported as $\mathrm{g} \mathrm{O}_{2} \mathrm{~m}^{-2}$. GPP was converted to carbon equivalents using a photosynthetic quotient of 1.4 (Harding et al. 2002).

Algal biomass: Phytoplankton species counts and chlorophyll analyses were conducted at monthly intervals at 6 locations in the upper bay. Observations were provided by the principal investigator (R. Lacouture, present address: Academy of Natural Sciences St. Leonard, MD). Prior to the data transfers, algae counts were converted to carbon using published values of biomass per individual. (Metadata on the collection and analyses can be found at ftp://ftp.chesapeakebay.net/Pub/Living_Resources/plank/phyto/mdphdoc. pdf.) These estimates of algal carbon content were used to compute phytoplankton carbon-to-chlorophyll ratio.

Chlorophyll, nutrients, and associated observations: The Chesapeake Bay Program conducted 12 to 18 sample cruises per year at approximately 50 stations throughout the bay. Chlorophyll, nutrient concentrations, and other observations for calibrating the model were obtained from an on-line database (www. chesapeakebay.net/data/index.htm; methods and metadata are available at the same site).
Model formulation. The eutrophication portion of the CBEMP considers 2 algal groups and 2 zooplankton groups. These groups interact with simulated cycles of carbon, nitrogen, phosphorus, and silica. Mass-balance equations for 24 state variables are solved on a 3-dimensional computational grid of over 12000 cells $(\sim 2.5 \times 2.5 \mathrm{~km} \times 1.5 \mathrm{~m})$. Details provided here focus on recent developments required to simulate primary production. Additional descriptions of model formulation and applications may be found elsewhere (Cerco \& Cole 1993, Cerco \& Meyers 2000).

Conservation of mass equation: The foundation of CBEMP is the solution to the 3-dimensional massconservation equation for a control volume. Control volumes correspond to cells on the model grid. CBEMP solves, for each volume and for each state variable, the equation:

$$
\frac{\delta V_{j} \cdot C_{j}}{\delta t}=\sum_{k=1}^{n} Q_{k} \cdot C_{k}+\sum_{k=1}^{n} A_{k} \cdot D_{k} \cdot \frac{\delta C}{\delta x_{k}}+\sum S_{j}
$$

where $V_{j}=$ volume of $j$ th control volume $\left(\mathrm{m}^{3}\right)_{;} C_{j}=$ concentration in $j$ th control volume $\left(\mathrm{g} \mathrm{m}^{-3}\right)_{i} t, x=$ temporal and spatial coordinates; $n=$ number of flow faces attached to $j$ th control volume; $Q_{k}=$ volumetric flow across flow face $k$ of $j$ th control volume $\left(\mathrm{m}^{3} \mathrm{~s}^{-1}\right) ; C_{k}=$ concentration in flow across face $k\left(\mathrm{~g} \mathrm{~m}^{-3}\right) ; A_{k}=$ area of flow face $k\left(\mathrm{~m}^{2}\right)_{i} D_{k}=$ diffusion coefficient at flow face $k\left(\mathrm{~m}^{2} \mathrm{~s}^{-1}\right) ; S_{j}=$ external loads and kinetic sources and sinks in $j$ th control volume $\left(\mathrm{g} \mathrm{s}^{-1}\right)$.

Solution to the mass-conservation equation is via the finite-difference method. The QUICKEST scheme (Leonard 1979) is used in the horizontal plane while a Crank-Nicholson scheme is used in the vertical. For notational simplicity, the transport terms are dropped in the succeeding kinetics formulations.

Phytoplankton kinetics: In the mainstem bay, 2 algal groups are simulated. The spring algal group comprises the diatoms that dominate saline waters from January to May. The summer algal group represents the assemblage of flagellates, diatoms, and other phytoplankton that dominate the system from May to December. Each algal group is represented by identical formulations. Differences between groups are determined by parameter specifications.

Algal sources and sinks in the conservation equation include production, respiration, predation, and settling. These are expressed as:

$$
\frac{\delta B}{\delta t}=(G-R) \cdot B-W a \frac{\delta B}{\delta z}-P R
$$

where $B=$ algal biomass, expressed as carbon $(\mathrm{gC}$ $\left.\mathrm{m}^{-3}\right) ; \quad G=$ growth $\left(\mathrm{d}^{-1}\right) ; R=$ respiration, $\mathrm{d}^{-1} ; W a=$ algal settling velocity $\left(\mathrm{m} \mathrm{d}^{-1}\right) ; P R=$ predation $(\mathrm{gC}$ $\left.\mathrm{m}^{-3} \mathrm{~d}^{-1}\right)$. 
Phytoplankton production is determined by the intensity of light, by the availability of nutrients, and by the ambient temperature.

Light: The influence of light on phytoplankton production is represented by a chlorophyll-specific production equation (Jassby \& Platt 1976):

$$
P^{B}=P_{\max }^{B} I / \sqrt{I^{2}+I_{k}^{2}}
$$

where $P^{B}=$ production $\left(\mathrm{g} \mathrm{C} \mathrm{g}^{-1} \mathrm{chl} \mathrm{d}^{-1}\right) ; P_{\text {max }}^{B}=$ maximum photosynthetic rate $\left(\mathrm{g} \mathrm{C}^{-1} \mathrm{chl} \mathrm{d}^{-1}\right) ; I=$ instantaneous irradiance (mol photons $\mathrm{m}^{-2} \mathrm{~d}^{-1}$ ).

Parameter $I_{k}$ is defined as the irradiance at which the initial slope of the production versus irradiance relationship intersects the value of $P^{B}$ max:

$$
I_{k}=\frac{P^{B} \max }{\alpha}
$$

where $\alpha=$ initial slope of production versus irradiance relationship ( $\left.\mathrm{g} \mathrm{C} \mathrm{g}^{-1} \mathrm{chl}\left[\mathrm{mol} \text { photons } \mathrm{m}^{-2}\right]^{-1}\right)$.

Chlorophyll-specific production rate is readily converted to carbon-specific growth rate, for use in Eq. (2), through division by the carbon-to-chlorophyll ratio:

$$
G=\frac{P^{B}}{\mathrm{CChl}}
$$

where $\mathrm{CChl}=$ carbon-to-chlorophyll ratio $\left(\mathrm{gC}^{-1}\right.$ chlorophyll a).

Nutrients: Carbon, nitrogen, and phosphorus are the primary nutrients required for algal growth. Diatoms require silica as well. The effects of nutrients on growth are described by the formulation commonly referred to as 'Michaelis-Menten' kinetics:

$$
f(N)=\frac{N}{K_{\mathrm{Hd}}+N}
$$

where $f(N)=$ nutrient limitation on algal production, $0 \leq f(N) \leq 1 ; N=$ concentration of dissolved nutrient $\left(\mathrm{g} \mathrm{m}^{-3}\right) ; K_{\mathrm{Hd}}=$ half-saturation constant for nutrient uptake $\left(\mathrm{g} \mathrm{m}^{-3}\right)$.

Temperature: Inspection of growth versus temperature curves (Eppley 1972, Canale \& Vogel 1974, Rhee \& Gotham 1981) indicates that algal growth rate increases as a function of temperature until an optimum temperature or temperature range is reached. Above the optimum temperature, growth rate declines. This behavior is described by a function similar to a Gaussian probability curve:

$$
\begin{aligned}
f(T) & =\mathrm{e}^{-K T_{\mathrm{g} 1}\left(T-T_{\mathrm{opt}}\right)^{2}} \text { when } T \leq T_{\mathrm{opt}} \\
& =\mathrm{e}^{-K T_{\mathrm{g} 2}\left(T_{\mathrm{opt}}-T\right)^{2}} \text { when } T>T_{\mathrm{opt}}
\end{aligned}
$$

where $f(T)=$ effect of temperature on growth, $0<f(T)$ $<1_{i} \mathrm{~T}=$ temperature, $\left({ }^{\circ} \mathrm{C}\right) ; T_{\text {opt }}=$ optimal temperature for algal growth $\left({ }^{\circ} \mathrm{C}\right) ; K T_{\mathrm{g} 1}=$ effect of temperature below $T_{\text {opt }}$ on growth $\left({ }^{\circ} \mathrm{C}^{-2}\right) ; K T_{\mathrm{g} 2}=$ effect of temperature above $T_{\text {opt }}$ on growth $\left({ }^{\circ} \mathrm{C}^{-2}\right)$.

Growth rate: No consensus exists on modeling the combined effects of nutrients and light on algal growth. Phytoplankton models that consider multiple nutrients commonly invoke 'the law of the minimum' so that the limitation to growth is determined by the single most limiting nutrient. This logic is not always extended to incorporate the light limitation. Classic models consider the product of the nutrient limitation and the light limitation (e.g. DiToro et al. 1971). Our own model employs an algorithm in which growth can be limited by nutrients, by light, or by both.

A production versus irradiance relationship is constructed for each model cell at each time step. First, maximum photosynthetic rate under ambient temperature and nutrient concentrations is determined:

$$
P^{B}{ }_{\max }(N, T)=P^{B} \max \cdot f(T) \cdot \frac{N}{K_{\mathrm{Hd}}+N}
$$

where $P_{\text {max }}^{B}(N, T)=$ maximum photosynthetic rate at ambient temperature and nutrient concentrations ( $\mathrm{gC}^{-1}$ chl d $\mathrm{d}^{-1}$ ). The single most limiting nutrient is employed in determining the nutrient limitation.

Next, parameter $I_{k}$ is derived from Eq. (4) using $P_{\text {max }}^{B}(N, T)$. Then the production versus irradiance relationship (Eq. 3) is constructed. The resulting curve exhibits 3 regions. For $I \gg I_{k}$, the value of the term $I / \sqrt{I^{2}+I_{k}^{2}}$ approaches unity and temperature and nutrients are the primary factors that influence production. For $I \ll I_{k}$, production is determined solely by and irradiance $I$. In the region where $I \sim I_{k}$, production is determined by the combined effects of temperature, nutrients and light. Instantaneous light in the model cell is used to obtain production at in situ irradiance and nutrient concentrations. This production is used in Eq. (5) to obtain specific growth rate.

Algal respiration: We considered 2 forms of respiration active and maintenance. Active respiration represents the release of carbon fixed during the photosynthetic process (Goldsworthy 1970) and is represented as a fraction of production. Maintenance respiration is the continuous energy expenditure required to maintain basic life processes. Maintenance respiration is modeled as an exponentially increasing function of temperature. Total respiration is represented as:

$$
R=P_{\text {resp }} \cdot G+B M_{\mathrm{r}} \cdot \mathrm{e}^{K T_{\mathrm{b}}\left(T-T_{\mathrm{r}}\right)}
$$

where $P_{\text {resp }}=$ active respiration $\left(0 \leq P_{\text {resp }} \leq 1\right) ; B M_{\mathrm{r}}=$ maintenance respiration at reference temperature $T_{\mathrm{r}}$, $\left(\mathrm{d}^{-1}\right) ; K T_{\mathrm{b}}=$ effect of temperature on maintenance respiration $\left({ }^{\circ} \mathrm{C}^{-1)} ; T_{\mathrm{r}}=\right.$ reference temperature for maintenance respiration $\left({ }^{\circ} \mathrm{C}\right)$. 
Predation: The predation term includes the activity of zooplankton, filter-feeding benthos, and other pelagic filter-feeders including planktivorous fishes. Formulation and results of the zooplankton and benthos computations may be found in Cerco \& Meyers (2000). Predation (PR) by other planktivores is modeled by assuming that predators clear a specific volume of water per unit biomass:

$$
P R=F \cdot B \cdot M
$$

where $F=$ filtration rate $\left(\mathrm{m}^{3} \mathrm{~g}^{-1}\right.$ predator $\left.\mathrm{C} \mathrm{d}^{-1}\right) ; M=$ herbivore biomass $\left(\mathrm{g} \mathrm{C} \mathrm{m}^{-3}\right)$.

Detailed specification of the spatial and temporal distribution of the predator population is impossible. One approach is to assume predator biomass is proportional to algal biomass, $M=\gamma B$, in which case Eq. (10) can be rewritten as:

$$
P R=\gamma \cdot F \cdot B^{2}
$$

Since neither $\gamma$ nor $F$ are known precisely, the logical approach is to combine their product into a single unknown, Phtl, determined during the model calibration procedure. Effect of temperature on predation is represented with the same formulation as the effect of temperature on respiration.

Model nitrogen cycle: Nitrogen is first divided into fractions available and unavailable for algal nutrition. Two available forms are considered: reduced and oxidized nitrogen. Reduced nitrogen consists primarily of ammonium; nitrate and nitrite comprise the oxidized nitrogen pool. The algal preference for reduced nitrogen (McCarthy et al. 1977) is expressed by an empirical function (Thomann \& Fitzpatrick 1982). Both available forms are used with equal efficiency and described with a single half-saturation coefficient for uptake.

Irradiance: Irradiance at the water surface is evaluated at each model time step by fitting a sin function to daily total irradiance. Irradiance declines exponentially with increasing depth below the surface. The diffuse attenuation coefficient is computed as a function of color and concentrations of organic and mineral solids (Cerco \& Meyers 2000).

Model primary production relationships. We derived 3 different primary production variables from the model for comparison with observations. $C_{\text {fix }}$ was computed:

$$
C_{\text {fix }}=\left[\frac{P^{B} \max }{\mathrm{CChl}} \cdot f(N) \cdot f(T) \cdot\left(1-P_{\text {resp }}\right)-B M_{\mathrm{r}}(T)\right] \cdot B
$$

The relationship for depth-integrated daily GPP was: GPP =

$$
\int_{0}^{D} \int_{0}^{Z_{1 \%}} \frac{P^{B} \max }{C C h l} \cdot \frac{I(t)}{\sqrt{I(t)^{2}+I_{k}^{2}}} \cdot f(N) \cdot f(T) \cdot B \cdot \mathrm{d} z \cdot \mathrm{d} t
$$

where $D=$ daylength $(1 \mathrm{~d}) ; Z_{1 \%}=$ depth at which irradiance is $1 \%$ of surface irradiance $(\mathrm{m}) ; I(t)=$ timevarying irradiance (mol photons $\mathrm{m}^{-2} \mathrm{~d}^{-1}$ ).

The relationship for depth-integrated daily NPP was:

$$
\begin{gathered}
\mathrm{NPP}=\int_{0}^{D} \int_{0}^{Z_{1} \%}\left\{\left[\frac{P^{\mathrm{B}} \max }{\mathrm{CChl}} \cdot \frac{I(t)}{\sqrt{I(t)^{2}+I_{k}^{2}}} \cdot f(N) \cdot f(T)\right] .\right. \\
\left.\left(1-P_{\mathrm{resp}}\right)-B M_{\mathrm{r}}(T)\right\} B \cdot \mathrm{d} z \cdot \mathrm{d} t
\end{gathered}
$$

Parameter evaluation. Model parameters are based on published values reported in a variety of units. For comparison with the model, reported parameters are converted to model units of meters, grams, and days.

Algal production parameters: Maximum photosynthetic rates, their temperature-dependence and parameter $I_{k}$ were based on observations by Harding et al. (1986) and by Smith \& Kemp (1995). The observed rates were subject to in situ nutrient limitations. Since the maximum photosynthetic rates employed by the model are for nutrient-unlimited situations, parameter values (Table 1) were specified at the upper range of reported rates based on the assumption that lower observations represented nutrient-limited conditions.

Respiration: Laws \& Chalup (1990) reported values of $0.03 \mathrm{~d}^{-1}$ for maintenance respiration and 0.28 for active respiration. Other investigators have found that from 15 to $35 \%$ of carbon fixed is lost to metabolism (Groeger \& Kimmel 1989, Kiddon et al. 1995). Model values (Table 1) were based on these reports. The temperature effect is from Tang \& Peters (1995).

Predation: Parameters for the zooplankton model have been reported elsewhere (Cerco \& Meyers 2000). The parameter that determines predation by other herbivores (Table 1) was specified to fit model results to observed algal biomass and production. Substantially lower rates were used for the spring algal group than for the summer algal group. The differential predation rates were based on the life cycle of Atlantic menhaden (Durbin \& Durbin 1975, Rippetoe 1993, Luo et al. 2001). Menhaden enter the bay in spring and initially feed almost entirely on zooplankton. As they mature, gill rakers develop to filter phytoplankton. Menhaden leave the bay in late fall and spawn in coastal ocean waters. Consequently, predation pressure exerted by menhaden on phytoplankton occurs primary in summer and early autumn, concurrent with dominance by the modeled summer algal group.

Carbon-to-chlorophyll ratio (CChl): CChl obtained from the enumerations varied over an enormous range. However, more than $70 \%$ of the enumerations indicated a CChl of less than 75:1, and the most common values were between 25:1 and 50:1 (Fig. 2a). We noted 2 characteristics of the data set. First, CChl was inversely related to light attenuation (Fig. 2c). For 
Table 1. Phytoplankton parameters and abbreviations used throughout text and in figures

\begin{tabular}{|c|c|c|c|c|}
\hline Symbol & Definition & Units & Spring group & Summer group \\
\hline Wa & Settling velocity & $\mathrm{m} \mathrm{d}^{-1}$ & 0.1 & 0.1 \\
\hline$P_{\max }^{B}$ & Maximum photosynthetic rate & $\mathrm{gC} \mathrm{g}^{-1} \mathrm{chl} \mathrm{d}^{-1}$ & 300 & 350 \\
\hline$\alpha$ & Initial slope of production versus irradiance relationship & $\begin{array}{c}\mathrm{gC} \mathrm{g}^{-1} \mathrm{chl}^{-1} \\
\left.(\text { mol photons m})^{-2}\right)^{-1}\end{array}$ & 8 & 8 \\
\hline$K_{\mathrm{Hn}}$ & Half-saturation concentration for nitrogen uptake & $\mathrm{g} \mathrm{N} \mathrm{m}^{-3}$ & 0.025 & 0.025 \\
\hline$K_{\mathrm{Hp}}$ & Half-saturation concentration for phosphorus uptake & $\mathrm{gP} \mathrm{m} \mathrm{m}^{-3}$ & 0.0025 & 0.0025 \\
\hline$K_{\mathrm{Hs}}$ & Half-saturation concentration for silica uptake & $\mathrm{g} \mathrm{Si} \mathrm{m}^{-3}$ & 0.03 & 0.01 \\
\hline$T_{\mathrm{opt}}$ & Optimal temperature for algal growth & ${ }^{\circ} \mathrm{C}$ & 16 & 25 \\
\hline$K T_{\mathrm{g} 1}$ & Effect of temperature below $T_{\text {opt }}$ on growth & ${ }^{\circ} \mathrm{C}^{-2}$ & 0.0018 & 0.0035 \\
\hline$K T_{\mathrm{g} 2}$ & Effect of temperature above $T_{\mathrm{opt}}$ on growth & ${ }^{\circ} \mathrm{C}^{-2}$ & 0.006 & 0 \\
\hline$P_{\text {resp }}$ & Active respiration & & 0.25 & 0.25 \\
\hline$B M_{\mathrm{r}}$ & Maintenance respiration at reference temperature & $\mathrm{d}^{-1}$ & 0.01 & 0.02 \\
\hline$T_{\mathrm{r}}$ & Reference temperature for metabolism & ${ }^{\circ} \mathrm{C}$ & 20 & 20 \\
\hline$K T_{\mathrm{b}}$ & Effect of temperature on metabolism & ${ }^{\circ} \mathrm{C}^{-1}$ & 0.0322 & 0.0322 \\
\hline$P_{\mathrm{htl}}$ & Rate of predation by other planktivores & $\mathrm{m}^{3} \mathrm{~g}^{-1} \mathrm{Cd}^{-1}$ & 0.1 to 0.2 & 0.5 to 2 \\
\hline$a$ & Minimum carbon-to-chlorophyll ratio & $\mathrm{g} \mathrm{C} \mathrm{g}^{-1} \mathrm{Chl}$ & 30 & 30 \\
\hline$b$ & Incremental carbon-to-chlorophyll ratio & $\mathrm{gC} \mathrm{g}^{-1} \mathrm{Chl}$ & 150 & 90 \\
\hline C & Effect of light attenuation on carbon-to-chlorophyll ratio & $\mathrm{m}$ & 1.18 & 1.19 \\
\hline $\mathrm{C}: \mathrm{N}$ & Carbon-to-nitrogen ratio & $\mathrm{gC} \mathrm{g} \mathrm{g}^{-1} \mathrm{~N}$ & 7.4 & 5.7 \\
\hline $\mathrm{C}: \mathrm{P}$ & Carbon-to-phosphorus ratio & $\mathrm{gC} \mathrm{g}^{-1} \mathrm{P}$ & 80 & 57 \\
\hline$C: S$ & Carbon-to-silica ratio & $\mathrm{gC}^{-1} \mathrm{~S}$ & 2.5 & 3.3 \\
\hline
\end{tabular}

example, at Stn CB2.2, in the turbidity maximum, median CChl was 32 while $K_{\mathrm{e}}$ was $2 \mathrm{~m}^{-1}$. At Stn CB5.2, roughly $140 \mathrm{~km}$ below the turbidity maximum, the median CChl was 80 while median $K_{\mathrm{e}}$ was $0.8 \mathrm{~m}^{-1}$. Algae grown in culture have demonstrated that $\mathrm{CChl}$ is proportional to irradiance (Cloern et al. 1995). This proportionality was apparent in our data set as an increase in CChl as a function of depth of light penetration of the water column.

A second characteristic, apparent at stations that experience a spring algal bloom, was a higher CChl during the bloom months (February to May) versus other months (Fig. 2b). The difference was too large to assign to the effect of light attenuation. The different ratios may have resulted from lower temperatures during bloom months relative to later months (Cloern et al. 1995) or may reflect a taxonomic property of bloom species versus other species.

$\mathrm{CChl}$ was represented in the model via the relationship:

$$
\text { CChl }=a+b \cdot \mathrm{e}^{-c K_{\mathrm{e}}}
$$

where $a=$ minimum carbon-to-chlorophyll ratio ( $\mathrm{gC}$ $\left.\mathrm{g}^{-1} \mathrm{chl}\right) ; b=$ incremental carbon-to-chlorophyll ratio at zero light attenuation $\left(\mathrm{g} \mathrm{C} \mathrm{g}^{-1} \mathrm{chl}\right) ; c=$ effect of light attenuation on carbon-to-chlorophyll ratio $(\mathrm{m}) ; K_{\mathrm{e}}=$ coefficient of diffuse light attenuation $\left(\mathrm{m}^{-1}\right)$.

The form of the relationship was based on inspection of the observations (Fig. 3). The minimum CChl was based on inspection and on an apparent physiological minimum value (Cloern et al. 1995). Remaining parameters were evaluated via regression (Table 1). Our procedure separated the spring bloom months from the remaining months. The presence of outliers and extreme values confounded parameter evaluation via least-squares regression of the raw data. Therefore, observations were 'binned' in light-attenuation increments of $0.05 \mathrm{~m}^{-1}$. Median CChl was computed for each bin. This procedure produced 20 or more representative values. The proposed relationship was logtransformed and parameters were evaluated using linear regression with median $\mathrm{CChl}$ as the dependent variable.

Composition: Algal nitrogen-to-carbon and phosphorus-to-carbon ratios were initially set to Redfield composition (Redfield et al. 1966), then adjusted to improve model fit to observed chlorophyll, nutrients and production (Table 1). Nitrogen composition remains close to Redfield composition while the phosphorus stoichiometry of the spring group reflects the limiting nature of this nutrient during the spring bloom. The silica fraction of the spring group (Table 1) was specified within the range of reported values (D'Elia et al. 1983, Parsons et al. 1984). Silica fraction of the summer group (Table 1) was specified at a lower value since diatoms comprise only a fraction of the summer species.

Nutrient uptake: Reported half-saturation concentrations for algal nutrient uptake in Chesapeake Bay are 0.001 to $0.008 \mathrm{~g} \mathrm{~N} \mathrm{~m}^{-3}$ for nitrogen (Wheeler et al. 1982) and 0.003 to $0.053 \mathrm{~g} \mathrm{P} \mathrm{m}^{-3}$ for phosphorus (Taft et al. 1975). The half-saturation concentrations reported by Wheeler et al. (1982) are much less than the range of values commonly reported for neritic phytoplank- 

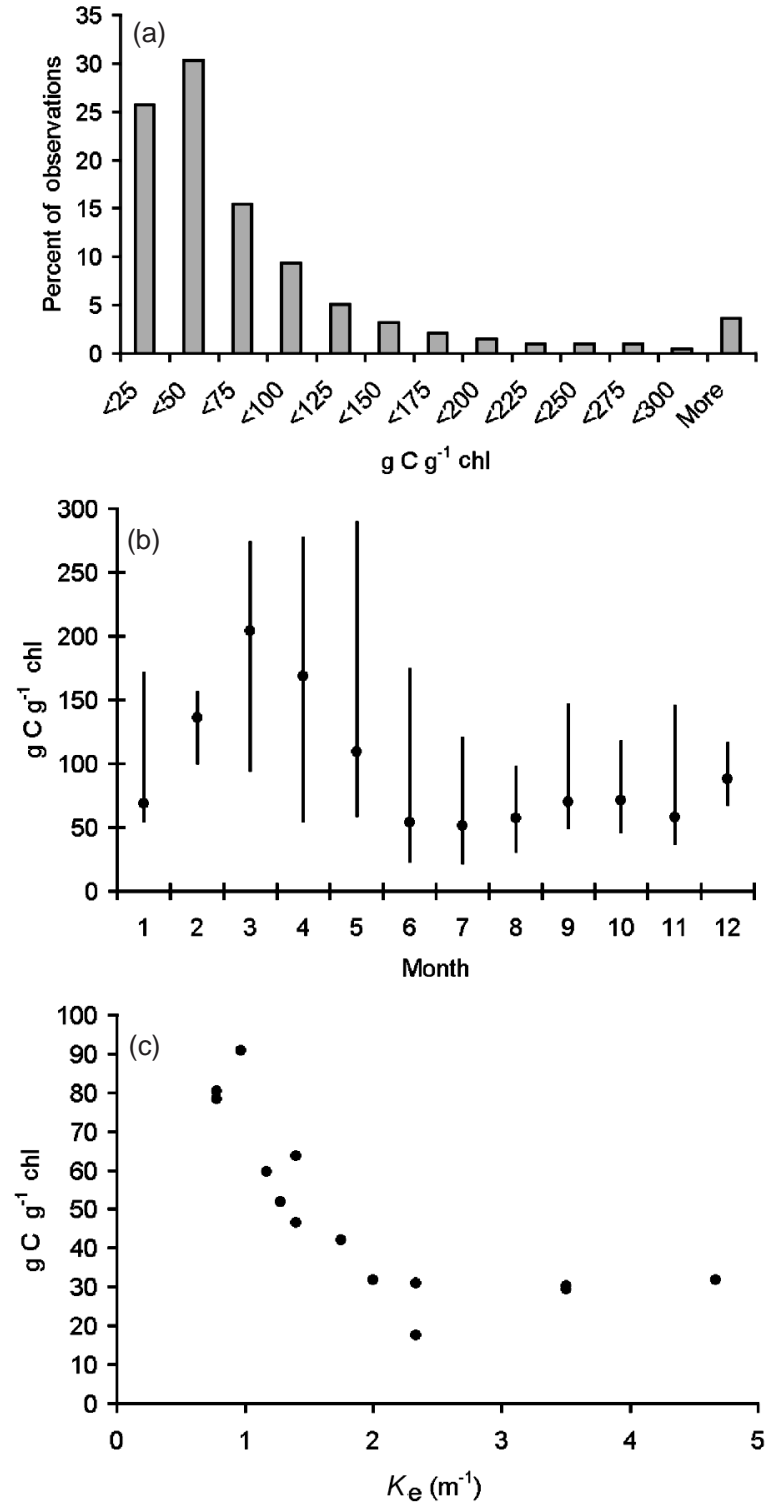

Fig. 2. Carbon-to-chlorophyll ratios (CChl). (a) histogram of observed ratios; (b) monthly values (median, 10th and 90th percentiles) at Stn CB5.2; (c) median ratio versus median light attenuation at 14 stations in Chesapeake Bay. $K_{\mathrm{e}}$ : coefficient of diffuse light attenuation $\left(\mathrm{m}^{-1}\right)$

ton. Means of values summarized by Eppley et al. (1969) are in the range 0.028 to $0.052 \mathrm{~g} \mathrm{~N} \mathrm{~m}^{-3}$, depending on substrate composition and plankton division. Model half-saturation constants (Table 1) corresponded with the lower end of reported ranges (Eppley et al. 1969, Taft et al. 1975).

The model half-saturation concentration for silica uptake by spring diatoms (Table 1) was within reported values ( 0.02 to $0.082 \mathrm{~g} \mathrm{Si} \mathrm{m}^{-3}$ ) for oceanic diatoms (Davis et al. 1978, Parsons et al. 1984). A lower half-saturation concentration was specified for the summer group to emphasize nitrogen limitation during this season (Fisher et al. 1999).

Algal settling rates: Reported algal settling rates typically range from 0.1 to $5 \mathrm{~m} \mathrm{~d}^{-1}$ (Bienfang et al. 1982, Riebesell 1989, Waite et al. 1992). In part, this variation is a function of physical factors related to alga size, shape, and density (Hutchinson 1967). The variability also reflects regulation of algal buoyancy as a function of nutritional status (Bienfang et al. 1982, Richardson \& Cullen 1995) and light (Waite et al. 1992). The algal settling rate employed in the model (Table 1) represents the net effect of all factors that result in downward transport of phytoplankton and is at the lower end of reported rates.

\section{RESULTS}

The CBEMP was applied to the period 1985 to 1994. Integration time step was $15 \mathrm{~min}$. Primary forcing functions included open-mouth boundary conditions (updated monthly, based on observations), solar radiation, and meteorology (updated daily based on observations), and distributed nutrient loads (updated daily, based on
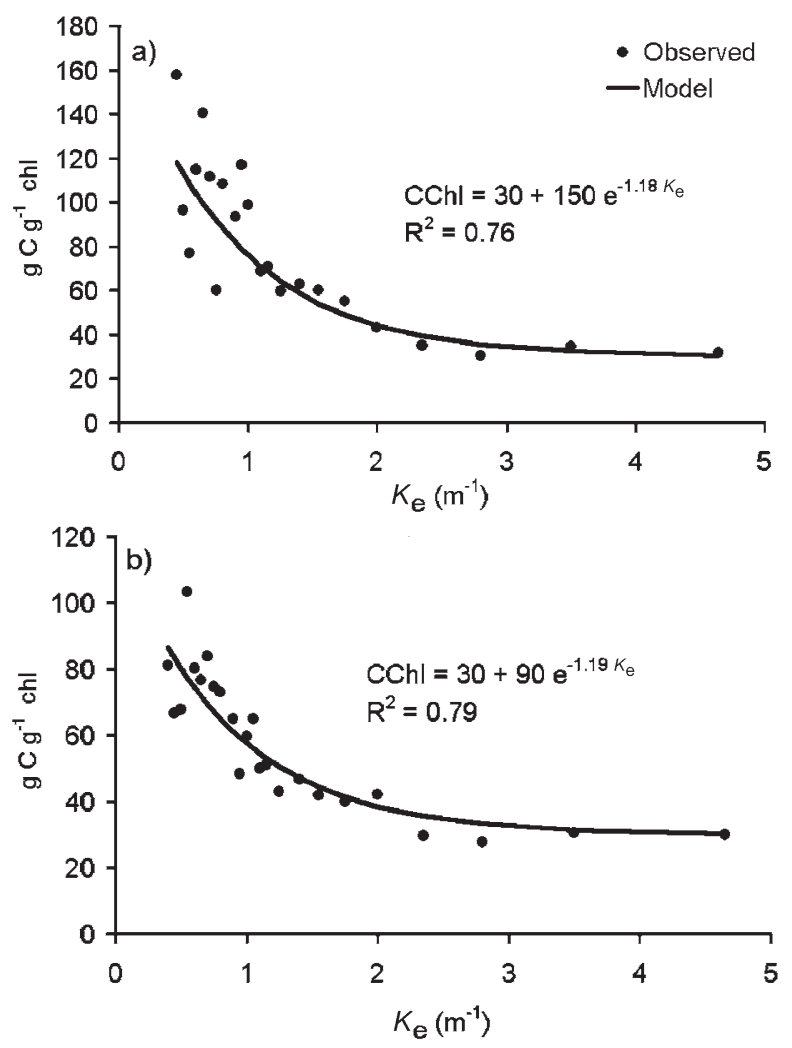

Fig. 3. Observed and modeled carbon:chlorophyll ratios (CChl) versus light attenuation for (a) spring and (b) summer algal groups 


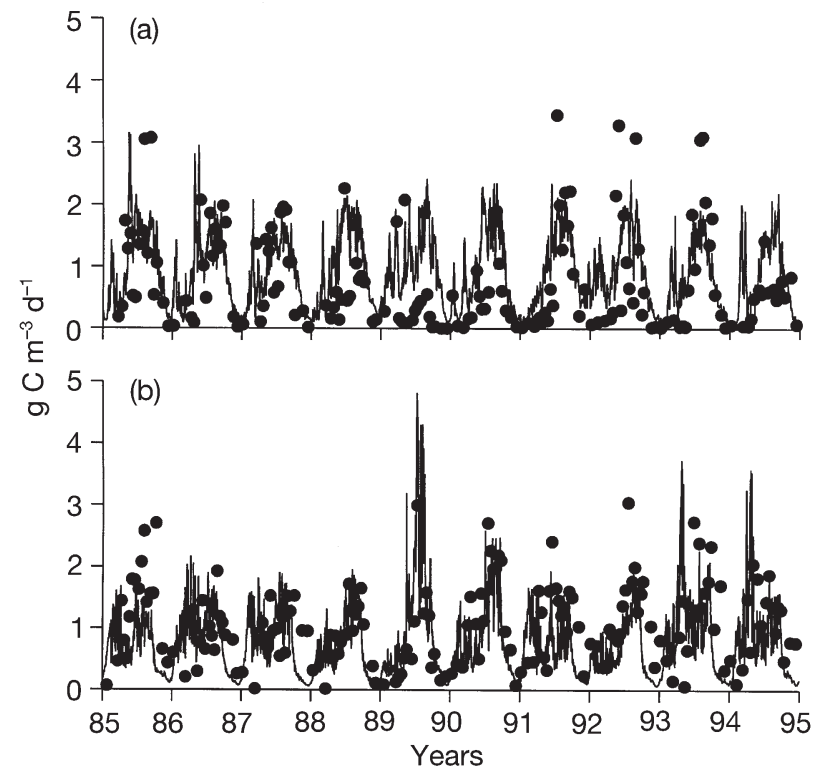

Fig. 4. Observed and computed carbon fixation $\left(C_{\text {fix }}\right)$ for (a) upper and (b) mid-Chesapeake Bay

inputs from a system-wide watershed model, Linker et al 1996). Output from the CBEMP was produced at $1 \mathrm{~d}$ increments. Analyses focused on 3 regions of the bay (Fig. 1). The northernmost region, designated CB2, is within the estuarine turbidity maximum. In this region, nutrients are abundant and light is considered to be the primary limit to algal production (Fisher et al. 1999). Both nutrient concentrations and light attenuation diminish with increasing distance down the bay axis. In the segment designated CB4, limiting factors exhibit a seasonal progression from light (winter), to phosphorus (spring), to nitrogen (summer) (Fisher et al. 1999). In the lower bay segment CB7, nitrogen is the primary limit to algal production (Fisher et al. 1999).

For $C_{\text {fix }}$, computations were drawn from the model cells corresponding to the locations of Stns CB2.2 (upper bay) and CB4.3C (mid-bay). For GPP, computations were drawn from the model cells corresponding to the locations of Stns NB (upper bay), MB (mid-bay), and SB (lower bay). For NPP, daily spatial averages

Table 2. Statistical summary of modeled and observed production. N: no. observed

\begin{tabular}{|lcccccc|}
\hline & \multicolumn{2}{c}{$\begin{array}{c}C_{\text {fix }}\left(\mathrm{g} \mathrm{C} \mathrm{m}^{-3} \mathrm{~d}^{-1}\right) \\
\text { Observed }\end{array}$} & \multicolumn{2}{c|}{ MPP $\left(\mathrm{g} \mathrm{C} \mathrm{m}^{-2} \mathrm{~d}^{-1}\right)$} & \multicolumn{2}{c|}{$\mathrm{GPP}\left(\mathrm{g} \mathrm{C} \mathrm{m}^{-2} \mathrm{~d}^{-1}\right)$} \\
Observed & Model & Observed & Model \\
\hline Mean & 1.00 & 1.00 & 0.88 & 0.82 & 1.38 & 1.13 \\
Median & 0.87 & 0.97 & 0.64 & 0.73 & 1.15 & 1.11 \\
Min. & 0.05 & 0.01 & 0.03 & 0.09 & 0.10 & 0.12 \\
Max. & 3.45 & 3.13 & 3.34 & 3.18 & 4.22 & 2.96 \\
SD & 0.73 & 0.58 & 0.82 & 0.46 & 1.07 & 0.72 \\
N & 319 & & 123 & & 60 & \\
\hline
\end{tabular}
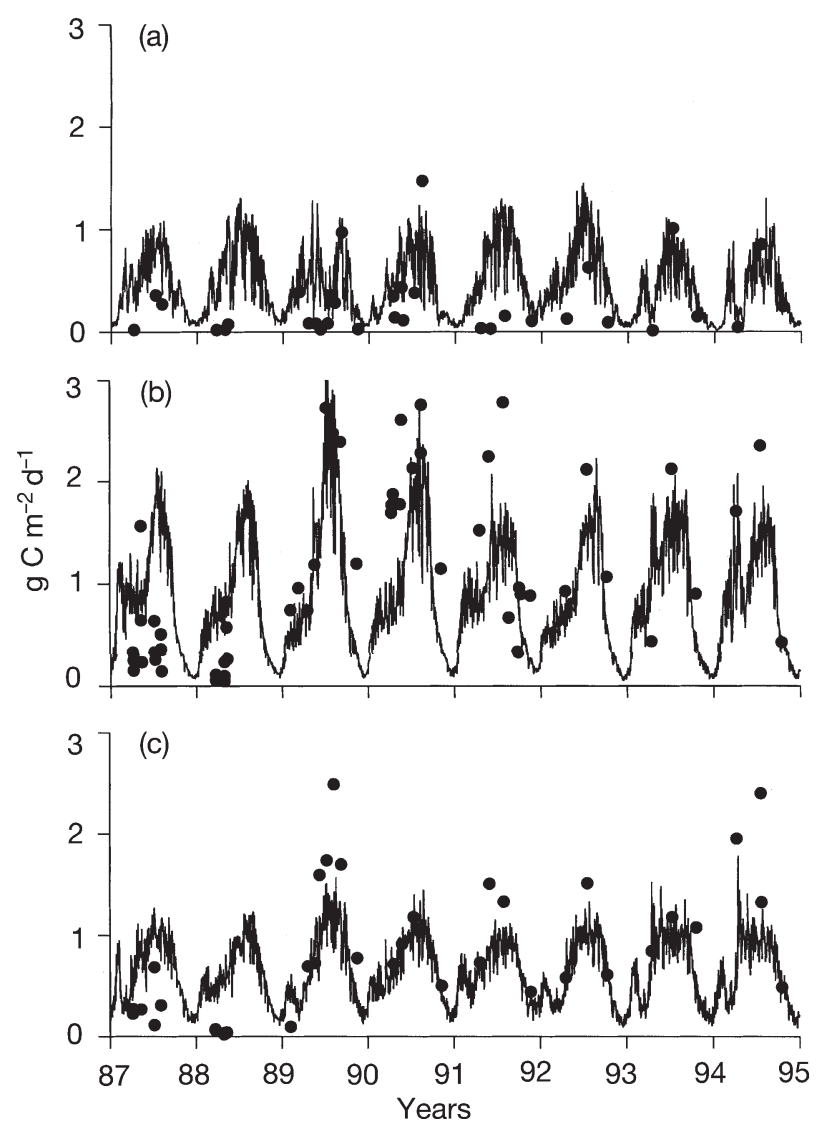

Fig. 5. Observed and computed NPP for (a) upper, (b) midand (c) lower Chesapeake Bay

over regions CB2 (upper bay), CB4 (mid-bay), and CB7 (lower bay) were compared to all observations within these regions.

\section{Seasonal and spatial trends}

Observations of $C_{\text {fix }}$ (Fig. 4) indicate a summer maximum, consistent with numerous studies (Malone et al. 1988, Smith \& Kemp 1995, Malone et al. 1996, Harding et al. 2002). The model shows the same seasonal trends as the observations. The model also shows a spatial trend that corresponds to the trend in nutrient availability. Highest fixation is in the upper bay, close to the Susquehanna River nutrient source. Lowest fixation is at the station most distant from the Susquehanna.

Observed NPP and GPP demonstrate significant summer maxima and substantial differences between the turbidity maximum and stations further 
Table 3. Regression summary of modeled versus observed carbon fixation $\left(C_{\text {fix }}\right)$, NPP, GPP, algal carbon, chlorophyll, light attenuation, available nitrogen

\begin{tabular}{|c|c|c|c|c|c|c|}
\hline Parameter & Slope & $95 \% \mathrm{CI}$ & Intercept & $95 \% \mathrm{CI}$ & $\mathrm{R}^{2}$ & $\mathrm{p}$ \\
\hline$C_{\text {fix }}\left(\mathrm{g} \mathrm{C} \mathrm{m}^{-3} \mathrm{~d}^{-1}\right)$ & 0.80 & 0.08 & 0.20 & 0.10 & 0.20 & $<0.0001$ \\
\hline $\operatorname{NPP}\left(\mathrm{g} \mathrm{C} \mathrm{m}^{-2} \mathrm{~d}^{-1}\right)$ & 0.57 & 0.08 & 0.32 & 0.10 & 0.26 & $<0.0001$ \\
\hline $\operatorname{GPP}\left(\mathrm{g} \mathrm{C} \mathrm{m}^{-2} \mathrm{~d}^{-1}\right)$ & 0.66 & 0.14 & 0.21 & 0.25 & 0.30 & $<0.0001$ \\
\hline Algal carbon $\left(\mathrm{g} \mathrm{C} \mathrm{m}^{-3}\right)$ & 0.50 & 0.05 & 0.14 & 0.03 & 0.34 & $<0.0001$ \\
\hline Chlorophyll $\left(\mathrm{mg} \mathrm{m}^{-3}\right)$ & 1.14 & 0.11 & 0.98 & 0.85 & 0.09 & $<0.0001$ \\
\hline Light attenuation $\left(\mathrm{m}^{-1}\right)$ & 1.27 & 0.08 & -0.27 & 0.11 & 0.46 & $<0.0001$ \\
\hline Available nitrogen $\left(\mathrm{g} \mathrm{N} \mathrm{m}^{-3}\right)$ & 1.04 & 0.05 & 0.01 & 0.03 & 0.73 & $<0.0001$ \\
\hline
\end{tabular}

downstream (Figs. 5 \& 6). Computations are consistent with the observed trends. Computed NPP and GPP peak in summer at all locations and are highest in midbay.

The NPP measures indicate that production in the lower bay is less than in the mid-bay (Fig. 5), while the GPP measures indicate production is equivalent at the 2 locations (Fig. 6). Our model behaves in agreement with the NPP measures. In the upper and mid-bay, our
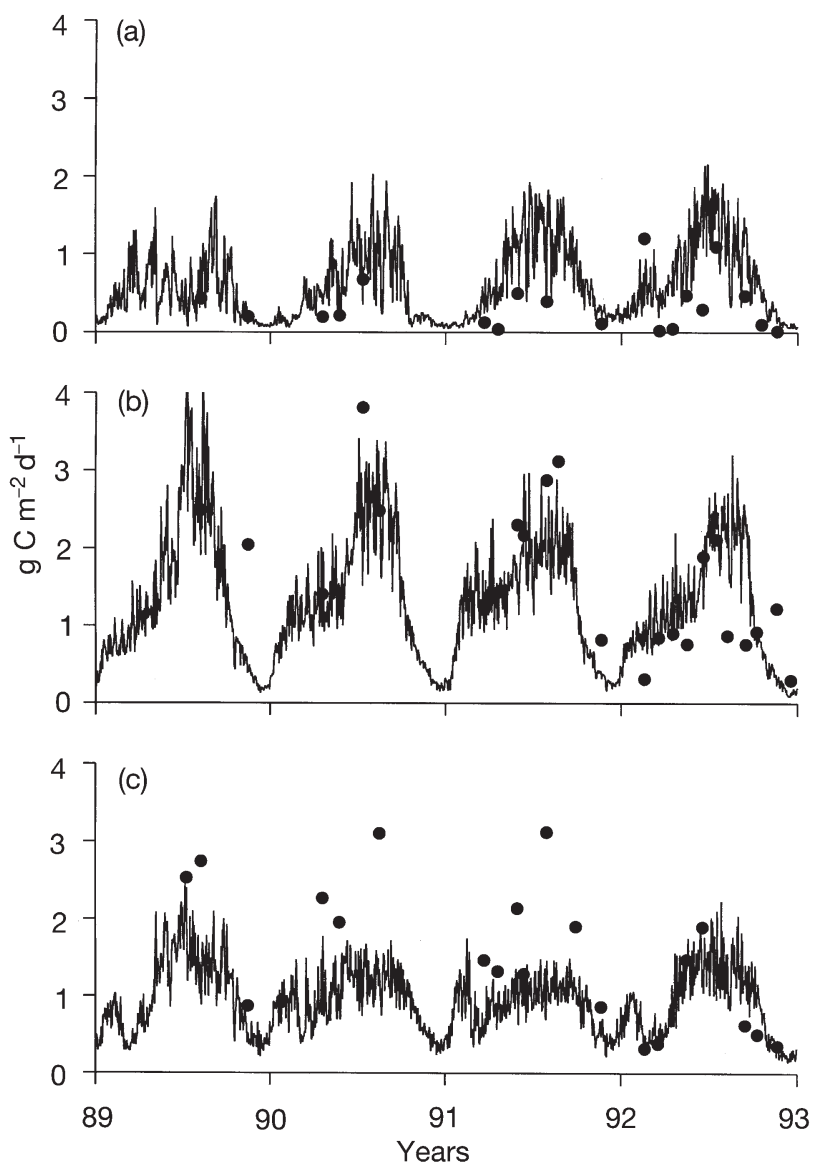

Fig. 6. Observed and computed GPP for (a) upper, (b) midand (c) lower Chesapeake Bay model reflects the excess of gross over net production (Fig. 7). The apparent large excess of gross over net production in the lower bay cannot be resolved. The disparity between NPP and GPP in the lower bay may reflect methodological differences in production measured by carbon fixation versus production measured by oxygen evolution.

\section{Statistical summaries of model performance}

Summaries of computed and observed primary production indicate robust model performance with regard to 3 independent measures of production (Table 2). Use of the paired $t$-test to compare individual observations with model calculations indicates that the mean difference between computed and observed $C_{\text {fix }}$ $(\mathrm{p}<0.01)$, NPP $(\mathrm{p}<0.01)$, and GPP $(0.01<\mathrm{p}<0.02)$ cannot be distinguished from zero.

Regression was used to compare individual computations of production, algal biomass, and limiting factors with observed quantities (Table 3). We emphasized nitrogen as the limiting nutrient since summer is the period of peak production (Harding et al. 2002),

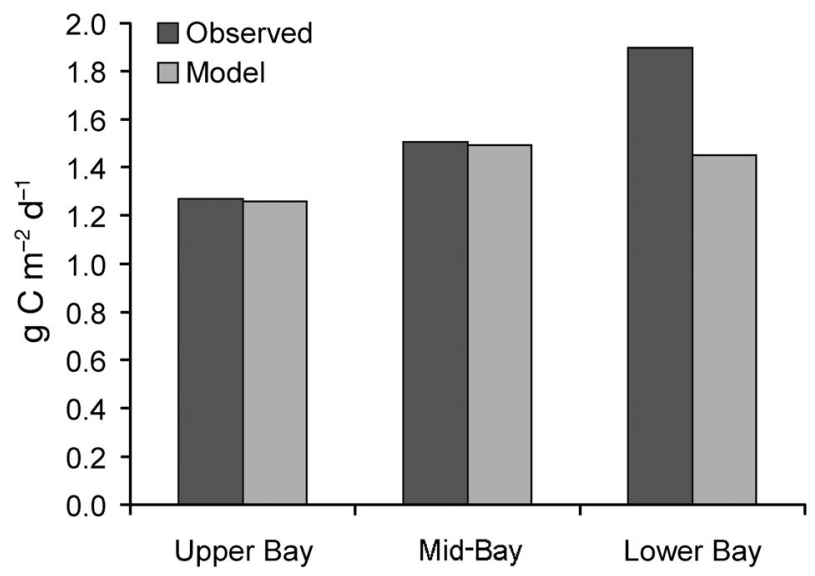

Fig. 7. Observed and computed GPP:NPP ratio in 3 areas of Chesapeake Bay 

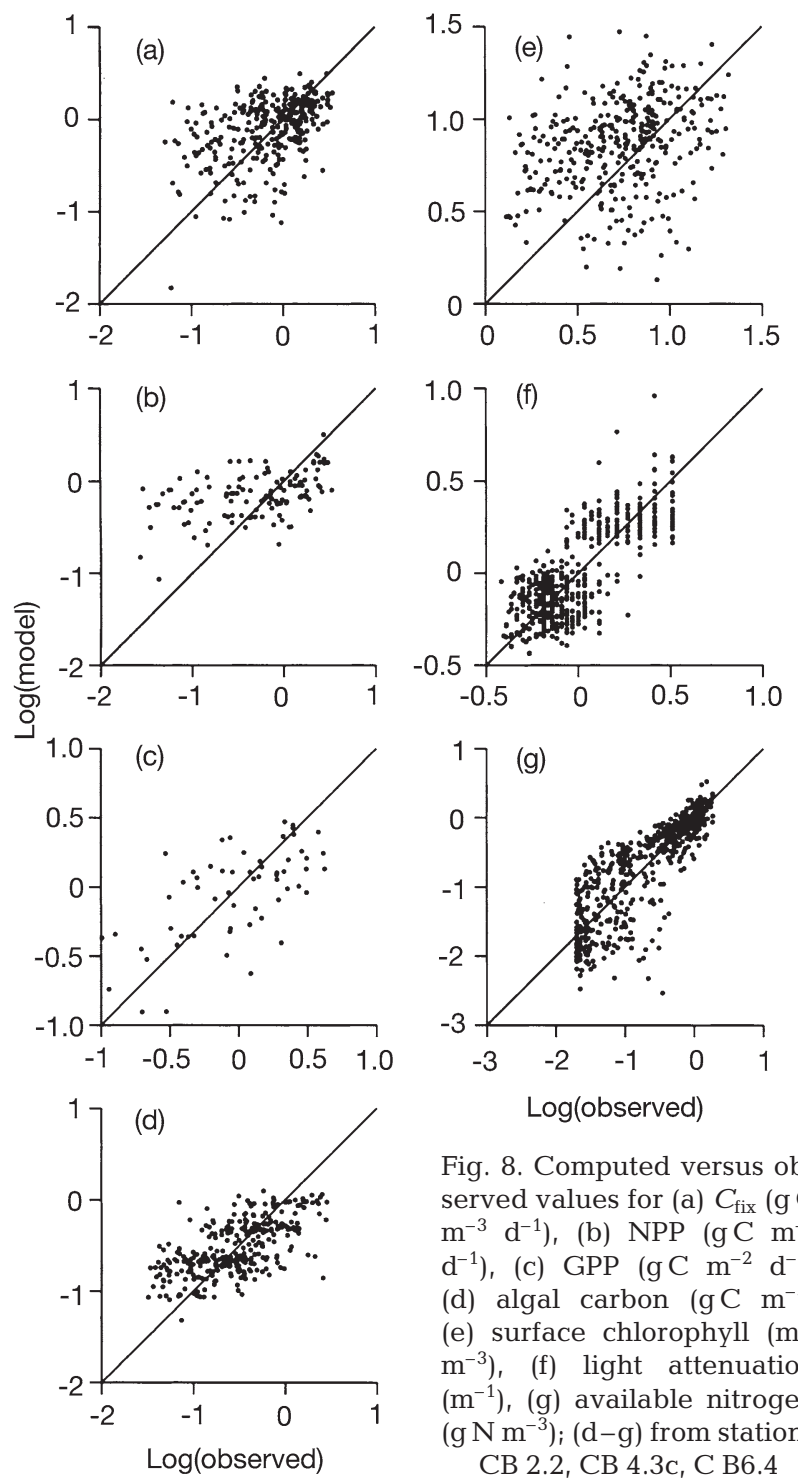

Fig. 8. Computed versus observed values for (a) $C_{\text {fix }}$ ( $\mathrm{g} \mathrm{C}$ $\left.\mathrm{m}^{-3} \mathrm{~d}^{-1}\right)$, (b) NPP $\left(\mathrm{g} \mathrm{C} \mathrm{m}^{-2}\right.$ $\left.\mathrm{d}^{-1}\right)$, (c) GPP $\left(\mathrm{g} \mathrm{C} \mathrm{m}^{-2} \mathrm{~d}^{-1}\right)$ (d) algal carbon $\left(\mathrm{g} \mathrm{C} \mathrm{m}^{-3}\right)$ (e) surface chlorophyll (mg $\mathrm{m}^{-3}$ ), (f) light attenuation $\left(\mathrm{m}^{-1}\right),(\mathrm{g})$ available nitrogen $\left(\mathrm{g} \mathrm{N} \mathrm{m}^{-3}\right) ;(\mathrm{d}-\mathrm{g})$ from stations CB 2.2, CB 4.3c, C B6.4

which is linked to nitrogen loading (Malone et al. 1988).

The regressions indicate that model performance can be divided into 2 categories. The slopes of computed versus observed chlorophyll, light attenuation, and available nitrogen exceed unity. The slope greater or equal to unity indicates that the model represents the largest quantities observed (Fig. 8). The slopes of computed versus observed $C_{\text {fix }}$ NPP, GPP, and algal carbon are all less than unity. The model cannot achieve the highest observed values and, in the case of NPP, overestimates the lowest values. Model performance, as expressed by the slope of computed versus observed, is best for quantities that are the result of direct measurement or laboratory analysis. Quantities that result from multiple analyses (primary production) or rely on tabulations (carbona- ceous biomass) produce extreme values that are not replicated by the model.

The $\mathrm{R}^{2}$ value for chlorophyll is notably low, although the slope is near unity and the regression is highly significant. The model has little power to reproduce individual chlorophyll observations, although the distribution of chlorophyll concentrations is represented. Correspondence between individual computed and observed values is influenced by the patchy distribution of chlorophyll. Weiss et al. (1997) found that the maximum distance over which chlorophyll observations are correlated in Chesapeake Bay ranges from $<1$ to $2 \mathrm{~km}$. Average cell dimensions in the mainstem bay are $\sim 2.5 \times 2.5 \mathrm{~km}$, and computed concentrations represent averages over this area. As a consequence of patchiness, point observations of chlorophyll are not necessarily representative of spatial averages over model cell sizes.

Chlorophyll observations are incorporated into the various primary production measures. The patchy distribution of chlorophyll creates, in effect, patchy estimates of production. We speculate that the presence of extreme chlorophyll observations creates extreme production observations that cannot be replicated by the model. Consequently, the model is better at representing average production than extremes.

\section{DISCUSSION}

\section{Specific growth rate}

The present model is distinguished from earlier versions and from models employed in similar applications by 2 primary features. The first is the determination of specific growth rate as the quotient of photosynthetic rate and CChl (Eq. 5). In the first version of the Chesapeake Bay model (Cerco \& Cole 1993) and in several investigative models (Fasham et al. 1990, McGillicuddy et al. 1995, Doney et al. 1996, Moll 1998), specific growth rate was specified directly.

Instantaneous, carbon-specific growth rates that result from the model relationship are high relative to commonly accepted values. Employing the maximum photosynthetic rate for the summer group, $350 \mathrm{~g} \mathrm{C} \mathrm{g}^{-1}$ chl d $\mathrm{d}^{-1}\left(14.6 \mathrm{~g} \mathrm{C} \mathrm{g}^{-1} \mathrm{chl} \mathrm{h}^{-1}\right)$, and a typical CChl of 50 yields an instantaneous specific growth rate of $7 \mathrm{~d}^{-1}$. In contrast, the classic work of Eppley (1972) indicates maximum specific growth rate is roughly $2 \mathrm{~d}^{-1}$ at $20^{\circ} \mathrm{C}$. Alternate investigations of primary production (Fasham et al. 1990, McGillicuddy et al. 1995, Doney et al. 1996, Moll 1998) employ growth rates of 0.66 to $2.9 \mathrm{~d}^{-1}$.

Recent work has indicated that classic growth rates of roughly $2 \mathrm{~d}^{-1}$ are, indeed, too low (Brush et al. 2002). The instantaneous rates employed in the model can be 
reconciled with lower reported rates through careful attention to definitions and growth rate comparisons. The instantaneous growth rate is not the daily average growth rate. The daily average growth rate can be obtained by

$$
G_{\mathrm{avg}}=\frac{1}{24} \cdot \int_{0}^{24} \frac{P^{B} \max }{\operatorname{CChl}} \cdot \frac{I_{(t)}}{\sqrt{I(t)^{2}+I_{k}^{2}}} \cdot \mathrm{d} t
$$

where $G_{\mathrm{avg}}=$ daily average growth rate $\left(\mathrm{d}^{-1}\right) ; I_{(t)}=$ instantaneous irradiance (mol photons $\mathrm{m}^{-2} \mathrm{~h}^{-1}$ ).

Employing a total daily irradiance of $60 \mathrm{~mol}$ photons $\mathrm{m}^{-2}$, a $12 \mathrm{~h}$ daylight period, and a sinusoidal time series of irradiance yields a daily-average specific growth rate of $3 \mathrm{~d}^{-1}$ for the summer group. This rate is still not realized within the water column, however. At a depth of $1 \mathrm{~m}$ (mid-point of model surface layer), with $K_{\mathrm{e}}=$ $1 \mathrm{~m}^{-1}$, daily average specific growth rate is reduced to $2.24 \mathrm{~d}^{-1}$. This growth rate is within conventional ranges and is subject to further reduction as a function of nutrient limitation and suboptimal temperature. This analysis indicates that conventional growth rates result in situ when maximum photosynthetic rate is influenced by light attenuation and averaged over $1 \mathrm{~d}$.

Models that initially specify maximum specific growth rate $\sim 2 \mathrm{~d}^{-1}$ and attenuate this rate because of the influence of daylength and other factors probably employ daily average growth that is much less than in situ growth. Resolution of the tendency of models to undercompute primary production (Brush et al. 2002) is not as simple as increasing the growth rate, however. To examine the effect of growth rate on computed production, we forced maximum instantaneous specific growth to $2 \mathrm{~d}^{-1}$ by fixing $\mathrm{CChl}$ and adjusting maximum photosynthetic rate. Computed production was substantially reduced in the upper bay but unchanged in the lower bay (Fig. 9). Production was proportional to growth rate where nutrients were abundant but insensitive to growth rate where nutrients were scarce. Reducing the maximum potential growth rate had little effect on production in the lower bay because phytoplankton growth was already restricted by nutrient depletion. To resolve the problem of undercomputing production in nutrient-depleted waters, we must consider nutrient recycling as well as algal growth rates.

\section{Predation by higher trophic levels}

A second distinctive feature of the model is the use of a quadratic term (Eq. 11) to represent predation by higher trophic levels not included in the model. Doney et al. (1996) incorporated a similar quadratic term that represented aggregation. A key difference between their formulation and the present model is that nutri-

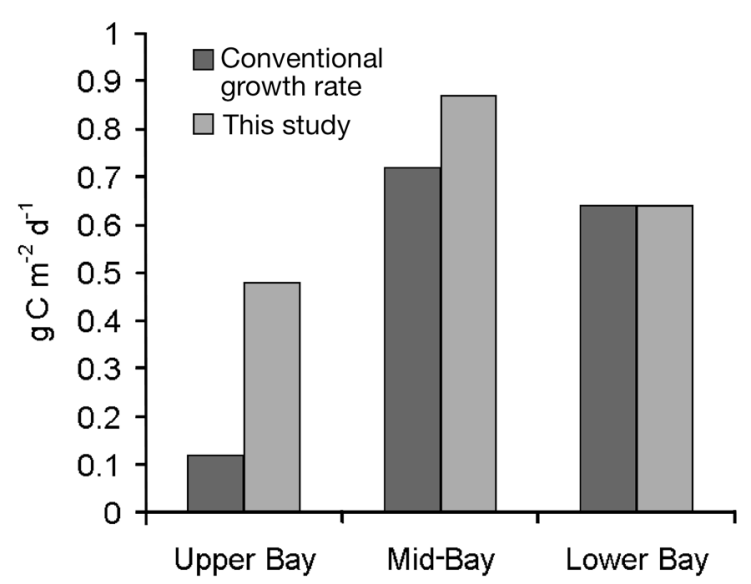

Fig. 9. Effect of growth rate on annual average NPP in 3 areas of Chesapeake Bay

ents incorporated in aggregated algae sink from the photic zone. The quadratic predation term recycles algal nutrients at the location where predation occurs. Empirical distribution coefficients route algal nutrients to dissolved inorganic $(40 \% \mathrm{~N}, 50 \% \mathrm{P})$, dissolved organic $(20 \% \mathrm{~N}, 40 \% \mathrm{P})$, and particulate organic (40\% N, $10 \%$ P) forms.

Computed primary production is sensitive to the specification of the predation term, $P_{\mathrm{htl}}$ (Fig. 10). Maximum production occurs at $P_{\mathrm{htl}} \sim 0.3$ although algal biomass declines monotonically from lower to high values of $P_{\mathrm{htl}}$. Consequently, maximum production occurs at moderate algal biomass rather than at low or high extremes. This behavior is explained by examining concentrations of dissolved inorganic phosphorus and available nitrogen. At the lowest predation rate examined, algal biomass was maximized but dissolved inorganic phosphorus was largely depleted. Due to the stringent nutrient limitation, growth was minimal. Production, which is the product of biomass and growth (Eq. 15), was low. As predation increased, biomass decreased but the nutrient limitation was relaxed as phosphorus bound up in algal biomass was released, through predation, to the water column. At moderate predation levels, the limiting nutrient in mid-bay tended toward nitrogen rather than phosphorus. Although biomass was diminished, relaxation of the stringent nutrient limitation allowed higher growth. Production was maximized. As predation approached the maximum rate examined, nutrient limitations to growth were eliminated but algal biomass was diminished so that the production was less than at lower predation rates. Steele \& Henderson (1992) found that use of a quadratic predation term to close a basic N-P-Z model resulted in higher nutrient concentrations than use of a linear term. Our own work confirms that the 

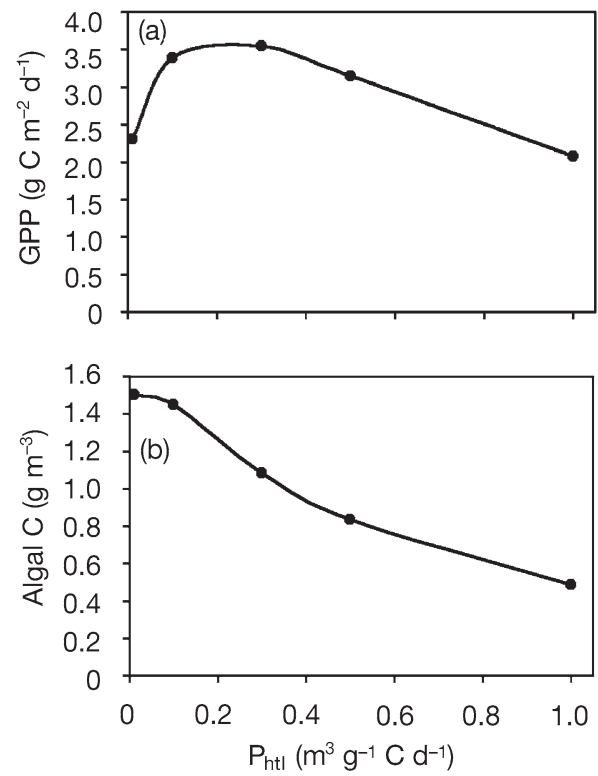
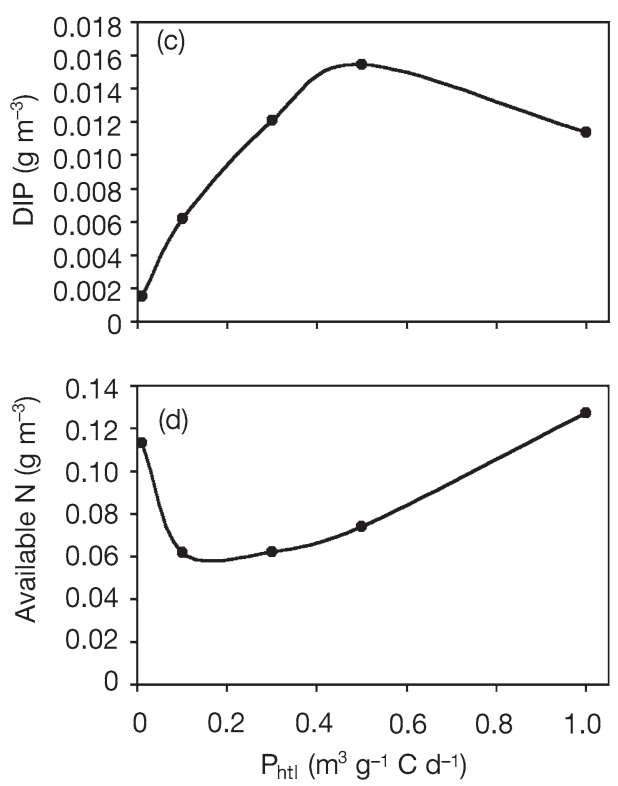

Fig. 10. Sensitivity of primary production to quadratic predation term at mid-bay location of Chesapeake Bay. Graphs indicate summer-average of (a) GPP, (b) surface algal biomass, (c) surface dissolved inorganic phosphorus, (d) surface available nitrogen

magnitude of the quadratic predation term has a strong influence on nutrient concentrations.

Predation by non-specific higher trophic levels is the dominant predation term in the model, consuming 60 to $75 \%$ of annual net production (Table 4). As originally conceived, the higher-trophic-level predation term was intended to simulate activity by menhaden. Attribution of this level of predation to menhaden seems unreasonable; a bioenergetics model (Luo et al. 2001) that estimated the carrying capacity of Chesapeake Bay for menhaden assumed that menhaden consume $10 \%$ of production.

Observations collected near our mid-bay station from March to October indicate predation by mesozooplankton consumes 12 to $103 \%$ of net production (White \& Roman 1992). Our model average over the same months indicates that mesozooplankton consume $19 \%$ of net production. Interestingly, both the observations and our model indicate that consumption can exceed net production, suggesting an import of phyto-

Table 4. Computed annual net algal production and consumption by predators

\begin{tabular}{|lcccc|}
\hline Location $\begin{array}{c}\mathrm{NPP} \\
\left(\mathrm{g} \mathrm{C} \mathrm{m}^{-2} \mathrm{~d}^{-1}\right)\end{array}$ & $\begin{array}{c}\text { higher } \\
\text { trophic levels }\end{array}$ & $\begin{array}{c}\text { Consumption }\left(\mathrm{g} \mathrm{C} \mathrm{m}^{-2} \mathrm{~d}^{-1}\right) \text { by: } \\
\text { microzooplankton }\end{array}$ & mesozooplankton \\
\hline $\mathrm{NB}$ & 0.48 & 0.36 & 0.03 & 0.01 \\
$\mathrm{MB}$ & 0.87 & 0.67 & 0.11 & 0.14 \\
$\mathrm{SB}$ & 0.64 & 0.38 & 0.10 & 0.13 \\
\hline
\end{tabular}

plankton to the mid-bay station. While the observations do not permit an exact determination of model performance versus actual mesozooplankton grazing, comparison with available measures of biomass and grazing indicates that performance is within the observed range.

Measures of microzooplankton grazing using the dilution technique (Gallegos 1989) indicate microzoplankton potentially consume 45 to $105 \%$ of the production in the Rhode River, a Chesapeake Bay tributary. The same methodology applied to Chesapeake Bay (McManus \& Ederington-Cantrell 1992) indicates that microzooplankton grazing rates average $57 \%$ of phytoplankton growth rates. Our annual estimates of microzooplankton consumption, 6 to $16 \%$ of net production, are low in comparison to the measures. The computed distribution of microzooplankton biomass is also low relative to observations. At the median, computed microzooplankton biomass $\left(0.005 \mathrm{~g} \mathrm{C} \mathrm{m}^{-3}\right)$ is about half that observed. Improvements to our microzooplankton model to double the biomass might raise computed consumption to 12 to $32 \%$ of net production.

Doubling the computed microzooplankton consumption still leaves a substantial fraction of non-specific predation. Benthic grazing directly on phytoplankton is negligible along the central axis of the bay, where the bottom is well below the photic zone and 
the mixed-layer depth. We attribute the remaining predation to heterotrophs not quantified in the microzooplankton observations. Microzooplankton sampling in the bay was conducted with a 44 m net. Brownlee \& Jacobs (1987), sampling in 2 Chesapeake Bay tributaries, found that the $44 \mathrm{~m}$ net captured less than half the biomass retained by a $20 \mathrm{~m}$ net. Johnson et al. (2003) estimated Chesapeake Bay microzooplankton biomass as high as $0.6 \mathrm{~g} \mathrm{C} \mathrm{m}^{-3}$, basing their enumerations on an Utermöhl chamber and fluorescent microscopy.

The quadratic formulation mimics a predator population that is strongly coupled to phytoplankton biomass and rapidly recycles nutrients into available form. While microzooplankton biomass ranges widely, the preponderance of observations is less than $0.1 \mathrm{~g} \mathrm{C}$ $\mathrm{m}^{-3}$ (Brownlee \& Jacobs 1987, Johnson et al. 2003). Microzooplankton biomass is 1 order of magnitude less than algal biomass and, consequently, a small fraction of the nutrient pool is sequestered in microzooplankton at any time. The instantaneous nutrient recycling provided by the predation term is, therefore, reasonable. In future applications, we may wish to re-parameterize the microzooplankton algorithm to increase computed biomass. An alternative would be to eliminate the dynamic computation of zooplankton and rely entirely on the quadratic predation term.

\section{CONCLUSIONS}

We have constructed a model that represents observed primary production rates while maintaining agreement with additional properties including algal biomass, chlorophyll, and light and nutrient limitation. The most significant model feature for the simultaneous computation of production and biomass, under nutrient-limited conditions, is the quadratic predation term. This term mimics a predator population that is tightly coupled to the phytoplankton biomass and that rapidly recycles algal nutrients at the location where predation occurs. From an ecological perspective, our model indicates that an optimum, moderate predation level exists. Primary production declines both above and below this optimum predation level. From a modeling perspective, our model indicates that the closure term used to represent predation warrants increased attention relative to conventional emphasis on production and limits to production.

Acknowledgements. L. W. Harding, W. M. Kemp, E. M. Smith, and R. Lacouture generously contributed original data for this research. The authors gratefully acknowledge commentary and reviews from L. W. Harding and W. M. Kemp, without which this contribution would not have been possible.

\section{LITERATURE CITED}

Behrenfield M, Falkowski P (1997) A consumer's guide to phytoplankton primary production models. Limnol Oceanogr 42(7):1479-1491

Bienfang P, Harrison P, Quarmby L (1982) Sinking rate response to depletion of nitrate, phosphate, and silicate in 4 marine diatoms. Mar Biol 67:295-302

Boynton W, Garber J, Summers R, Kemp W (1995) Inputs, transformations, and transport of nitrogen and phosphorus in Chesapeake Bay and selected tributaries. Estuaries 18: 285-314

Brownlee D, Jacobs F (1987) Mesozooplankton and microzooplankton in the Chesapeake Bay. In: Majumdar S, Hall L, Austin $\mathrm{H}$ (eds) Contaminant problems and management of living Chesapeake Bay resources. Pennsylvania Academy of Science, Philadelphia, PA, 217-269

Brush M, Brawley J, Nixon S, Kremer J (2002) Modeling phytoplankton production: problems with the Eppley curve and an empirical alternative. Mar Ecol Prog Ser 238: 31-45

Canale R, Vogel A (1974) Effects of temperature on phytoplankton growth. J Environ Eng 100:231-241

Cerco C, Cole T (1993) Three-dimensional eutrophication model of Chesapeake Bay. J Environ Eng 119:1006-1025

Cerco C, Meyers M (2000) Tributary refinements to the Chesapeake Bay Model. J Environ Eng 126:164-174

Cloern J, Grenz C, Vidergar-Lucas L (1995) An empirical model of the phytoplankton chlorophyll:carbon ratio - the conversion factor between productivity and growth rate. Limnol Oceanogr 40:1313-1321

Davis C, Breitner N, Harrison P (1978) Continuous culture of marine diatoms under silicon limitation. 3. A model of Si-limited diatom growth. Limnol Oceanogr 23:41-52

D'Elia C, Nelson D, Boynton W (1983) Chesapeake Bay nutrient and plankton dynamics. III. The annual cycle of silicon. Geochim Cosmochim Acta 47:1945-1955

DiToro D (2001) Sediment flux modeling. John Wiley \& Sons, New York

DiToro D, O'Connor D, Thomann R (1971) A dynamic model of the phytoplankton population in the Sacramento-San Joaquin delta. In: Nonequilibrium systems in water chemistry. American Chemical Society, Washington, DC

Doney S, Glover D, Najjar R (1996) A new coupled, onedimensional biological-physical model for the upper ocean: applications to the JGOFS Bermuda Atlantic Timeseries study (BATS) site. Deep-Sea Res II 43:591-624

Durbin A, Durbin, E (1975) Grazing rates of the Atlantic menhaden Brevoortia tyrannus as a function of particle size and concentration. Mar Biol 33:265-277

Eppley R (1972) Temperature and phytoplankton growth in the sea. Fish Bull 70:1063-1085

Eppley R, Rogers J, McCarthy J (1969) Half-saturation constants for uptake of nitrate and ammonium by marine phytoplankton. Limnol Oceanogr 14:912-920

Fasham M, Ducklow H, McKelvie S (1990) A nitrogen-based model of plankton dynamics in the oceanic mixed layer. J Mar Res 48:591-639

Fisher T, Peele E, Ammerman J, Harding L (1992) Nutrient limitation of phytoplankton in Chesapeake Bay. Mar Ecol Prog Ser 82:51-63

Fisher T, Gustafson A, Sellner K, Lacouture R and 6 others (1999) Spatial and temporal variation of resource limitation in Chesapeake Bay. Mar Biol 133:763-778

Gallegos C (1989) Microzooplankton grazing on phytoplankton in the Rhode River, Maryland: nonlinear feeding kinetics. Mar Ecol Prog Ser 57:23-33 
Goldsworthy A (1970) Photorespiration. Bot Rev 36:321-340

Groeger A, Kimmel B (1989) Relationship between photosynthetic and respiratory carbon metabolism in freshwater plankton. Hydrobiologia 173:107-117

Harding L, Meeson B, Fisher T (1986) Phytoplankton in three east coast estuaries: photosynthesis-light curves and patterns of carbon assimilation. Estuar Coast Shelf Sci 23: 773-806

Harding L, Mallonee M, Perry E (2002) Toward a predictive understanding of primary productivity in a temperate, partially stratified estuary. Estuar Coast Shelf Sci 55: 437-463

Hutchinson G (1967) A treatise on limnology, Vol II. John Wiley \& Sons, New York

Jassby A, Platt T (1976) Mathematical formulation of the relationship between photosynthesis and light for phytoplankton. Limnol Oceanogr 21:540-547

Johnson B, Kim K, Heath R, Hsieh B, Butler L (1993) Validation of a three-dimensional hydrodynamic model of Chesapeake Bay. J Hydraul Eng 199:2-20

Johnson M, Rome M, Stoecker D (2003) Microzooplankton grazing on Prorocentrum minimim and Karlodinium micrum in Chesapeake Bay. Limnol Oceanogr 48:238-248

Kiddon J, Bender M, Marra J (1995) Production and respiration in the 1989 North Atlantic spring bloom: an analysis of irradiance-dependent changes. Deep-Sea Res 42: $553-576$

Laws E, Chalup M (1990) A microalgal growth model. Limnol Oceanogr 35(3):597-608

Leonard B (1979) A stable and accurate convection modelling procedure based on quadratic upstream interpolation. Comp Methods Appl Mechanics Engin 19:59-98

Linker L, Stigall C, Chang C, Donigian A (1996) Aquatic accounting: Chesapeake Bay watershed model quantifies nutrient loads. Water Environ Technol 8:48-52

Luo J, Hartman K, Brandt S, Cerco C, Rippetoe T (2001) A spatially-explicit approach for estimating carrying capacity: an application for the Atlantic menhaden (Brevoortia tyrannus) in Chesapeake Bay. Estuaries 24:545-556

Malone T, Crocker L, Pike S, Wendler B (1988) Influences of river flow on the dynamics of phytoplankton production in a partially stratified estuary. Mar Ecol Prog Ser 48: 235-249

Malone T, Conley D, Fisher T, Glibert P, Harding, Sellner K (1996) Scales of nutrient-limited phytoplankton productivity in Chesapeake Bay. Estuaries 19:371-385

McCarthy J, Taylor W, Taft J (1977) Nitrogenous nutrition of the plankton in the Chesapeake Bay. 1. Nutrient availability and phytoplankton preferences. Limnol Oceanogr 22:996-1011

McGillicuddy D, McCarthy J, Robinson A (1995) Coupled physical and biological modeling of the spring bloom in the North Atlantic. I: Model formulation and one dimensional bloom processes. Deep-Sea Res I Pap 42:1313-1357

McManus G, Ederington-Cantrell M (1992) Phytoplankton pigments and growth rates, and microzooplankton graz-

Editorial responsibility: Otto Kinne (Editor),

Oldendorf/Luhe, Germany ing in a large temperate estuary. Mar Ecol Prog Ser 87: $77-85$

Moll A (1998) Regional distribution of primary production in the North Sea simulated by a three-dimensional model. J Mar Syst 16:151-170

Parsons T, Takahashi M, Hargrave B (1984) Biological oceanographic processes, 3rd edn. Pergamon Press, Oxford

Pritchard D (1967) Observations of circulation in coastal plain estuaries. In: Lauff G (ed) Estuaries. American Association for the Advancement of Science, Washington, DC, p 37-44

Redfield A, Ketchum B, Richards F (1966) The influence of organisms on the composition of sea-water. In: Hill MN (ed) The sea, Vol II. Wiley Interscience, New York, p 26-48

Rhee G, Gotham I (1981) The effect of environmental factors on phytoplankton growth: temperature and the interactions of temperature with nutrient limitation. Limnol Oceanogr 26:635-648

Richardson T, Cullen J (1995) Changes in buoyancy and chemical composition during growth of a coastal marine diatom: ecological and biogeochemical consequences. Mar Ecol Prog Ser 128:77-90

Riebesell U (1989) Comparison of sinking and sedimentation rate measurements in a diatom winter/spring bloom. Mar Ecol Prog Ser 54:109-119

Rippetoe T (1993) Production and energetics of Atlantic menhaden in Chesapeake Bay. MSc thesis, University of Maryland, College Park

Smith E, Kemp W (1995) Seasonal and regional variations in plankton community production and respiration for Chesapeake Bay. Mar Ecol Prog Ser 116:217-231

Steele J, Henderson E (1992) The role of predation in plankton models. J Plankton Res 14:157-172

Strickland JHD, Parsons TR (1972) A practical handbook of seawater analysis, 2nd edn. Bull Fish Res Board Can 167:1-310

Taft J, Taylor W, McCarthy J (1975) Uptake and release of phosphorus by phytoplankton in the Chesapeake Bay estuary, USA. Mar Biol 33:21-32

Tang E, Peters R (1995) The allometry of algal respiration. J Plankton Res 17(2):303-315

Thomann R, Fitzpatrick J (1982) Calibration and verification of a mathematical model of the eutrophication of the Potomac Estuary. HydroQual, Mahwah, NJ

Waite A, Thompson P, Harrison P (1992) Does energy control the sinking rates of marine diatoms? Limnol Oceanogr 37: 468-477

Weiss G, Harding L, Itsweire E, Campbell J (1997) Characterizing lateral variability of phytoplankton chlorophyll in Chesapeake Bay with aircraft ocean color data. Mar Ecol Prog Ser 149:183-199

Wheeler P, Gilbert P, McCarthy J (1982) Ammonium uptake and incorporation by Chesapeake Bay phytoplankton: short-term uptake kinetics. Limnol Oceanogr 27:1113-1128

White J, Roman M (1992) Seasonal study of grazing by metazoan zooplankton in the mesohaline Chesapeake Bay. Mar Ecol Prog Ser 86:251-261

Submitted: June 5, 2003; Accepted: April 20, 2004

Proofs received from author(s): October 22, 2004 